\title{
Quality of life in adults with sickle cell disease: an integrative review of the literature
}

\author{
Qualidade de vida em adultos com doença falciforme: revisão integrativa da literatura \\ Cualidad de vida en adultos con enfermedad falciforme: revisión integradora de la literatura
}

\section{Sandra Luzinete Felix de Freitas', Maria Lucia Ivo', Maria Stella Figueiredo", Maria Auxiliadora de Souza Gerk"II, Cristina Brandt Nunes" ${ }^{\text {III }}$ Fernando de Freitas Monteiro ${ }^{\text {IV }}$}

' Universidade Federal de Mato Grosso do Sul, Postgraduate Program in Health and Development in the Central-West Region. Campo Grande, Mato Grosso do Sul, Brazil.

"Universidade Federal de São Paulo, Department of Clinical and Experimental Oncology. São Paulo, Brazil.

I'I Universidade Federal de Mato Grosso do Sul, Center for Biological and Health Sciences, Undergraduate Program in Nursing. Campo Grande, Mato Grosso do Sul, Brazil.

"v Associação Beneficente de Campo Grande, Medical Residency in Psychiatry. Campo Grande, Mato Grosso do Sul, Brazil

\section{How to cite this article:}

Freitas SLF, Ivo ML, Figueiredo MS, Gerk MAS, Nunes CB, Monteiro FF. Quality of life in adults with sickle cell disease: an integrative review of the literature. Rev Bras Enferm [Internet]. 2018;71(1):195-205.

DOI: http://dx.doi.org/ 10.1590/0034-7167-2016-0409

\section{Submission: 07-20-2016 Approval: 03-18-2017}

\section{ABSTRACT}

Objective: To identify the available evidence in the literature on health-related quality of life in adults with sickle cell disease. Method: integrative review of MEDLINE, CUMED, LILACS and SciELO databases, from articles developed in this area, published between 2005 and 2015, in English, Portuguese or Spanish. Results: 22 articles were included, six scales were used to evaluate health-related quality of life scores: three generic and three specific. No specific scale for adults with sickle cell disease has been adapted to Brazilian Portuguese so far. Patients affected by frequent painful crises, with low adherence to treatment, had a compromised quality of life. Conclusion: Selected studies have shown that patients with sickle cell disease have worse scores than the general population. These indicators should be instrumental to the nurse in the proposal of interventions and strategies of assistance and socio-educational, with a view to improving the quality of life of this clientele.

Descriptors: Quality of Life; Sickle Hemoglobin; Inquiries and Questionnaires; Nursing; Based on Evidence.

\section{RESUMO}

Objetivo: Identificar as evidências disponíveis na literatura sobre qualidade de vida relacionada à saúde em adultos com doença falciforme. Método: revisão integrativa nas bases de dados MEDLINE, CUMED, LILACS e SciELO, de artigos provenientes de estudos desenvolvidos nesta temática, publicados entre 2005 a 2015, em inglês, português ou espanhol. Resultados: foram incluídos 22 artigos, sendo utilizadas seis escalas para avaliar os escores de qualidade de vida relacionada à saúde: três genéricas e três específicas. Nenhuma escala específica para adultos com doença falciforme foi adaptada para o português brasileiro até o momento. Pacientes acometidos por crises dolorosas frequentes, com baixa adesão ao tratamento, apresentaram comprometimento da qualidade de vida. Conclusão: Os estudos selecionados evidenciaram que os pacientes com doença falciforme têm piores escores do que a população em geral. Esses indicadores deveriam instrumentalizar o enfermeiro na proposição de intervenções e estratégias assistenciais e socioeducativas, com vistas a melhorar a qualidade de vida desta clientela.

Descritores: Qualidade de Vida; Hemoglobina Falciforme; Inquéritos e Questionários; Enfermagem; Baseada em Evidência.

\section{RESUMEN}

Objetivo: Identificar las evidencias disponibles en la literatura sobre cualidad de vida relacionada a la salud en adultos con enfermedad falciforme. Método: revisión integradora en las bases de datos MEDLINE,CUMED,LILACS y SciELO, de artículos provenientes de estudios desarrollados en esta temática, publicados entre 2005 y 2015, en inglés, portugués o español. Resultados: fueron incluidos 22 artículos, siendo utilizadas seis escalas para evaluar las puntuaciones de cualidad de vida relacionada a la salud: tres genéricas y 
tres específicas. Ninguna escala específica para adultos con enfermedad falciforme fue adaptada para el portugués brasileño hasta el momento. Pacientes acometidos por crisis dolorosas frecuentes, con baja adhesión al tratamiento, presentaron comprometimiento de la cualidad de vida. Conclusión: Los estudios seleccionados evidenciaron que los pacientes con enfermedad falciforme tienen peores puntuaciones que la población en general. Esos indicadores deberían instrumentalizar el enfermero en la proposición de intervenciones y estrategias asistenciales y socioeducativas, con vistas a mejorar la cualidad de vida de esta clientela.

Descriptores: Cualidad de Vida; Hemoglobina Falciforme; Investigaciones y Cuestionarios; Enfermería; Basada en Evidencia.

\section{CORRESPONDING AUTHOR Sandra Luzinete Felix de Freitas E-mail: sandra.freitas@ufms.br}

\section{INTRODUCTION}

The term sickle cell disease (DF) is used to denote a group of genetic disorders in which there is a predominant hemoglobin $(\mathrm{Hb})$ variant called $\mathrm{HbS}$, which originates from a point mutation resulting in the substitution of glutamic acid by valine at position 6 of the $\beta$-globin ${ }^{(1)}$. The most frequent forms of FD are: sickle cell anemia, homozygous and more severe form (HbSS); HbS hemoglobinopathy in association with another $\mathrm{Hb}$ variant $(\mathrm{HbC})$ and $\mathrm{Sb}$ - thalassemia $(\mathrm{Sb}-\mathrm{tal})$, which presents the HbS $\beta$ - tal or HbS $\beta+$-tal subtypes ${ }^{(2)}$.

This mutation produces changes in the structure of $\mathrm{HbS}$ that, under conditions of low oxygen concentration, undergoes polymerization. These polymer chains inside the erythrocytes cause a change in their shape, loss of characteristic deformability, acquiring the shape of sickle (falcization). Sickle red cells cause vaso-occlusion and trigger inflammatory process, with consequent tissue damage. Patients usually present several complications, which begin in childhood, as a result of repeated vaso-occlusive episodes, chronic inflammation and hemolysis ${ }^{(3)}$.

Characterized by severe musculoskeletal pain and chronic hemolytic anemia, FD can present several complications, including: infections, heart disease, renal failure, stroke, leg ulcers and proliferative retinopathy ${ }^{(2-5)}$.

In addition to pain and suffering, this disease can lead to decreased coping ability and difficulty for these people to become productive citizens, which impacts the life of the patient and reduces their quality of life $(\mathrm{QoL})^{(5)}$. Understanding the perception of the individual with chronic disease on his QOL makes it possible to know the necessary adjustment processes in the face of the chronicity of the disease and to create subsidies that support the interventions of the health professionals.

The World Health Organization ${ }^{(6)}$ defines QOL as 'the individual's perception of their position in life in the context of the culture and value system in which they live and in relation to their goals, expectations, standards and their interests'. This term has been used by the population in general, but has stimulated countless studies developed by professionals who provide assistance to people affected by various diseases.

The term health-related quality of life (HRQoL), in addition to describing the QoL of a specific population, also examines the impact of diseases or health interventions on QoL, and has arisen with increased survival and prevalence of chronic disease $^{(7)}$. The QV is evaluated through instruments, consisting of different numbers of items (or questions) grouped into domains or areas. They are formulated mostly in the English language and directed to the population that uses that language, and should be translated into other languages when necessary, always following strictly the norms of the literature pre-established for their translation ${ }^{(8)}$.

These instruments, also called scales or questionnaires, may be generic or specific. As an advantage, generic scales can be applied to any population and, therefore, allow comparison between people with different diseases. The specifics are more sensitive, since they are designed to evaluate the QoL of individuals belonging to specific populations (children, adults, men, women, elderly) or with certain diseases (cancer, diabetes, rheumatoid arthritis) ${ }^{(9)}$.

Given the importance of knowing how adults with DF evaluate their QOL, this integrative review of the literature was proposed with the objective of identifying the evidence on HRQoL in this disease.

\section{METHOD}

\section{Study design}

It is a descriptive study that used the integrative review because it is one of the resources of the Evidence-Based Practice that enables the researcher to analyze and synthesize the scientific knowledge about the object of the study, through the results of previous research, as well as to identify gaps that must be fulfilled through further investigation ${ }^{(10)}$.

\section{Methodological reference and the respective steps}

During the development of this integrative review, the six stages were rigorously covered: 1 ) Identification of the theme and selection of the hypothesis or the guiding question of research; 2) Establishment of criteria for inclusion and exclusion of studies, sampling and search in the literature; 3) Data collection and categorization of studies; 4) Critical analysis of included studies; 5) Discussion of the results and 6) Synthesis and presentation of the review (Figure 1$)^{(11)}$.

A broad guiding question was adopted for this study: what evidence is available in the literature about HRQoL assessment in adults with FD, which scales were used, and of which, which have already been validated in Brazil? The bibliographic survey was carried out from August 2015 to January 2016, in the electronic databases MEDLINE (Medical Literature Analysis and Retrieval System Online), CUMED (National Center of Information of Medical Sciences of Cuba), LILACS (Latin American Literature and the Caribbean in Health Sciences) and SciELO (Scientific Electronic Library Online). The first three were accessed by the Virtual Health Library (BVS / BIREME) operating platform. 


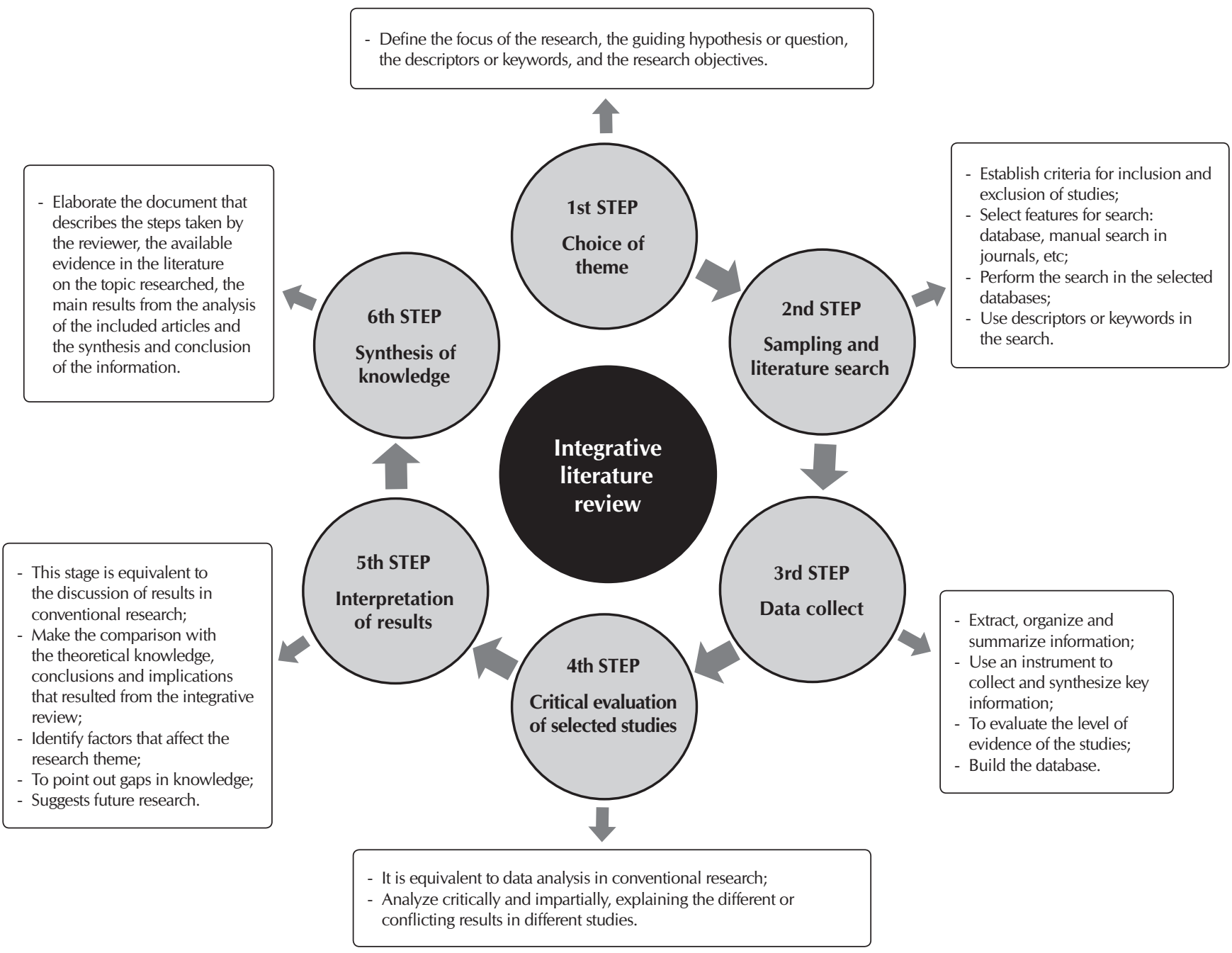

Figure 1 - Stages of integrative literature review

To search the databases, we used some controlled descriptors (quality of life, sickle cell disease and questionnaires); keywords that do not appear as controlled descriptors in Health Sciences Descriptors (health related quality of life, instrument and scale) and Boolean operators (AND / OR), in different associations among themselves, in the English, Portuguese and Spanish languages. There was a need to use keywords, since not all the terms that represent the subject to be studied were registered in the website Descriptors in Health Sciences.

Inclusion criteria were: original articles from studies whose objective was to evaluate QoL in adults with FD, published in the period 2005 to 2015, with abstracts available and that could be accessed in full by the online medium in English, Portuguese or Spanish.

In order to avoid bias in the selection of articles, during the search and selection phase, two researchers acted independently ${ }^{(10)}$. After selecting the articles, a data collection instrument was developed by the main author to synthesize each study selected in the space of a page, with relevant content, containing the following information: article identification (title, periodical, descriptors, base data, authors, country where it was developed, year and language of publication); Methodological characteristics (type of study, level of evidence, sample characterization and scale of evaluation of HRQoL used), objective, results and conclusion.

After analyzing each article, the reviewers organized and synthesized the information, creating an Excel ${ }^{\circledR}$ database that was easy to access and manipulate.

\section{RESULTS}

Figure 2 illustrates the process of capturing articles in the MEDLINE, CUMED, LILACS and SciELO databases, according to the associations of keywords and / or descriptors; the number of articles selected and excluded according to the inclusion criteria; language of publication; design and level of evidence of the studies.

The search in the databases, with the four associations of keywords, resulted in a total of 802 publications, being 521 (64.9\%) in English, 253 (31.5\%) in Portuguese and 28 (3.5 \%) in Spanish. After submission to the inclusion criteria, 22 articles were selected (Figure 2). 
Guiding question: what are the available evidence in the literature on the evaluation of $\mathrm{HRQ}$ in adults with FD, which scales were used and, of these, which have already been validated in Brazil?

Research conducted from August 2015 to January 2016

Keyword associations (in English, Portuguese and Spanish) and Boolean operators used:
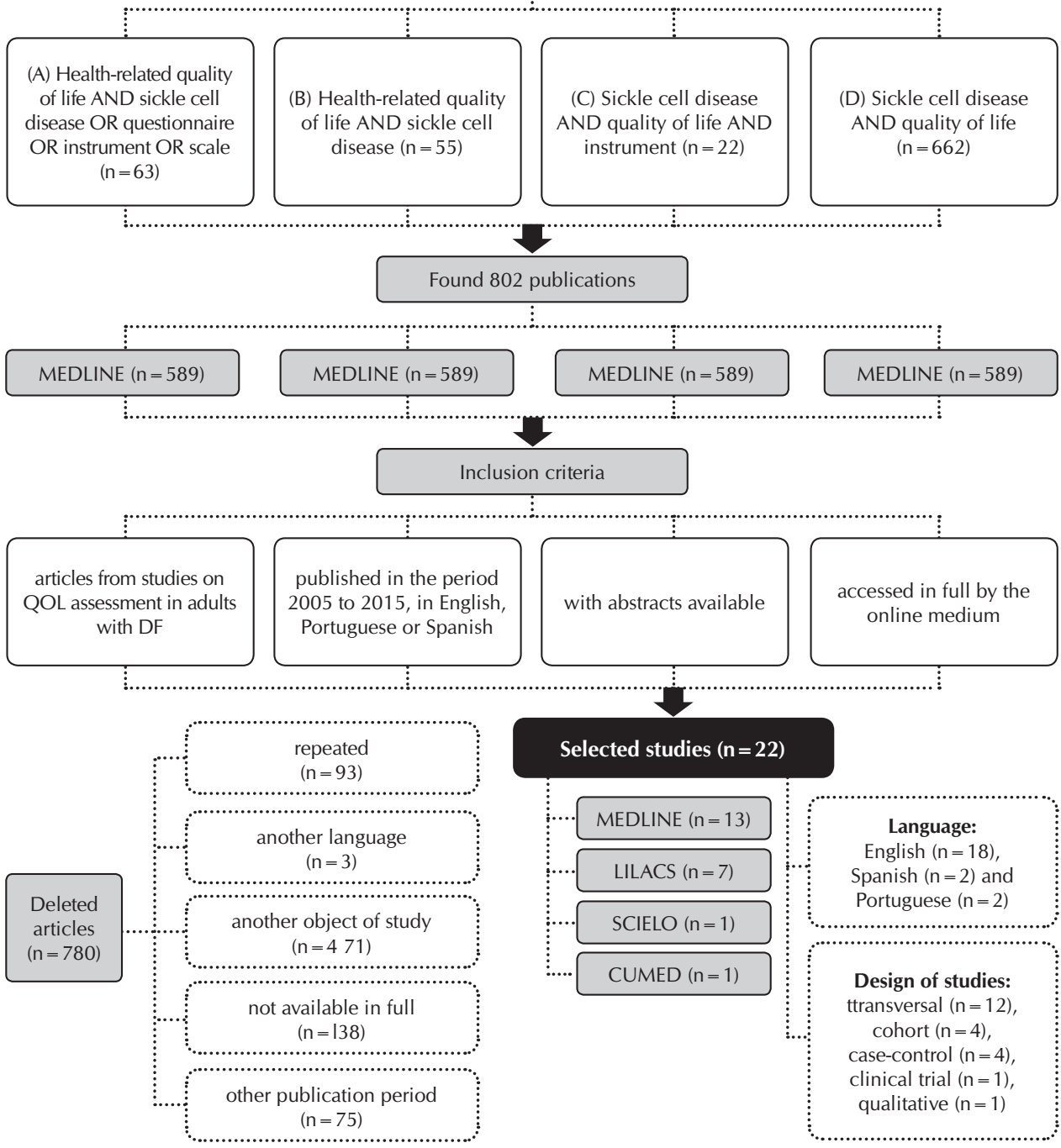

Note: QRS (Health-Related Quality of Life), MEDLINE (Medical Literature Analysis and Retrieval System Online) LILACS (Latin American and Caribbean Literature in Health Sciences), SciELO (Scientific Electronic Library Online) and CUMED of Medical Sciences of Cuba)

Figure 2 - Flowchart of the abstraction of selected articles in the MEDLINE, CUMED, LILACS and SciELO databases, according to inclusion criteria, Campo Grande, Mato Grosso do Sul, Brazil, 2016
It was observed that, although the studies were very well delineated $^{(12)}, 13$ (59.1\%) were level VI (12 cross-sectional studies and one qualitative study), eight (36.4\%) level IV articles two cohort studies and four case-control studies) and one (4.5\%) level II (clinical, randomized, double-blind, controlled trial).

In Chart 1 it is possible to visualize the distribution of the 22 articles analyzed, according to authors, periodical, periodical classification, year of publication, country where it was developed, scale of evaluation of HRQoL used by the researchers, objectives, delineation and level of evidence of each study, in addition to the database.

Regarding the geographic distribution, eight (36.4\%) studies were developed in Brazil, six (27.3\%) in the United States of America (USA), three $(13.6 \%)$ in Jamaica, two $(9.1 \%)$ in Saudi Arabia two $(9.1 \%)$ in Cuba and one $(4.5 \%)$ in the Netherlands.

After analyzing and synthesizing the articles selected for this review, in order to facilitate reading and comprehension, we chose to group the results and discussion into three categories: Sociodemographic aspects and genotypes of the participants of the selected studies; Scales used to assess health-related quality of life; and Quality of life of patients with sickle cell disease.

Chart 1 - Articles selected according to the associations of controlled descriptors and / or keywords used, authors, title, periodicals, year of publication, country where it was developed and database

\begin{tabular}{|c|c|c|c|c|c|}
\hline Base & Author, title of article & $\begin{array}{l}\text { Periodic, classification, } \\
\text { year and country }\end{array}$ & Scale & Objectives & $\begin{array}{c}\text { Design and level } \\
\text { of evidence }\end{array}$ \\
\hline 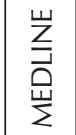 & $\begin{array}{l}\text { McClish et al }{ }^{(13)} \text {. Health related } \\
\text { quality of life in sickle cell patients: } \\
\text { the PiSCES project. }\end{array}$ & $\begin{array}{c}\text { Health Qual Life } \\
\text { Outcomes (B1), 2005, } \\
\text { USA }\end{array}$ & $\begin{array}{l}0 \\
\stackrel{\tilde{m}}{\omega}\end{array}$ & $\begin{array}{c}\text { To evaluate the QOL of patients } \\
\text { with DF participating in The Pain } \\
\text { in Sickle Cell Epidemiology Study } \\
\text { (PiSCES) }\end{array}$ & $\begin{array}{l}\text { Cohort - groups: } \\
\text { asthma, cystic fibrosis } \\
\text { and dialysis. } \\
\text { Level IV }\end{array}$ \\
\hline
\end{tabular}

To be continued 
Chart 1

\begin{tabular}{|c|c|c|c|c|c|}
\hline Base & Author, title of article & $\begin{array}{l}\text { Periodic, classification, } \\
\text { year and country }\end{array}$ & Scale & Objectives & $\begin{array}{l}\text { Design and level } \\
\text { of evidence }\end{array}$ \\
\hline \multirow{12}{*}{ 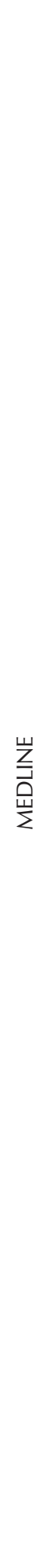 } & $\begin{array}{c}\text { Ballas et al }{ }^{(14)} \text {. Hydroxyurea and } \\
\text { sickle cell anemia: effect on quality } \\
\text { of life. }\end{array}$ & $\begin{array}{c}\text { Health Qual Life } \\
\text { Outcomes (B1), 2006, } \\
\text { USA }\end{array}$ & $\underset{m}{\stackrel{m}{\omega}}$ & $\begin{array}{l}\text { To evaluate the effect of hydroxyurea } \\
\text { (HU) on the quality of life of patients } \\
\text { with sickle cell anemia (AF) }\end{array}$ & $\begin{array}{l}\text { Clinical, double-blind, } \\
\text { randomized trial } \\
\text { Level II }\end{array}$ \\
\hline & $\begin{array}{l}\text { Asnani et al }{ }^{(4)} \text {. Component structure } \\
\text { of the SF-36 in Jamaicans with sickle } \\
\text { cell disease. }\end{array}$ & $\begin{array}{l}\text { West Indian Med J } \\
\text { (B1), 2007, Jamaica }\end{array}$ & $\underset{m}{\tilde{m}}$ & $\begin{array}{c}\text { To evaluate the structural } \\
\text { component of SF36 in Jamaican } \\
\text { patients with DF }\end{array}$ & $\begin{array}{l}\text { Randomized cohort, } \\
\text { random sample } \\
\text { Level IV }\end{array}$ \\
\hline & $\begin{array}{l}\text { Adams-Graves et al(5). Development } \\
\text { and validation of SIMS: an instrument } \\
\text { for measuring quality of life of adults } \\
\text { with sickle cell disease. }\end{array}$ & $\begin{array}{l}\text { Am J Hematol (A1) } \\
2008 \text { USA }\end{array}$ & $\sum_{n}^{\infty}$ & $\begin{array}{l}\text { To develop the Sickle Disease } \\
\text { Impact Measurement Scale (SIMS), } \\
\text { an instrument to measure the } \\
\text { quality of life of adults with DF }\end{array}$ & $\begin{array}{c}\text { Case control - creation } \\
\text { and testing of scale } \\
\text { with two groups. } \\
\text { Level IV }\end{array}$ \\
\hline & $\begin{array}{l}\text { Asnani et } \mathrm{al}^{(1)} \text {. Quality of life in } \\
\text { patients with sickle cell disease in } \\
\text { Jamaica: rural-urban differences. }\end{array}$ & $\begin{array}{l}\text { Rural Remote Health } \\
2008 \text { Jamaica }\end{array}$ & $\begin{array}{l}\stackrel{0}{N} \\
\frac{1}{n}\end{array}$ & $\begin{array}{l}\text { To know the differences between } \\
\text { the QOL of patients with FD who } \\
\text { live in urban and rural areas }\end{array}$ & $\begin{array}{c}\text { Analytical } \\
\text { observational Level IV }\end{array}$ \\
\hline & $\begin{array}{l}\text { Asnani et al }{ }^{(15)} \text {. Utility of WHOQOL- } \\
\text { BREF in measuring quality of life in } \\
\text { sickle cell disease. }\end{array}$ & $\begin{array}{l}\text { Health Qual Life } \\
\text { Outcomes } \\
2009 \text { Jamaica }\end{array}$ & 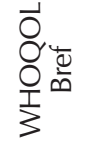 & $\begin{array}{l}\text { To study the usefulness of } \\
\text { WHOQOL-Bref in the QOL } \\
\text { measurement of patients with DF }\end{array}$ & $\begin{array}{l}\text { Control case } \\
\text { Level IV }\end{array}$ \\
\hline & $\begin{array}{l}\text { van Tuijn et al }{ }^{(16)} \text {. Pain rate and } \\
\text { social circumstances rather } \\
\text { than cumulative organ damage } \\
\text { determine the quality of life in } \\
\text { adults with sickle cell disease }\end{array}$ & $\begin{array}{l}\text { Am J Hematol (A1), } \\
\text { 2010, Netherlands }\end{array}$ & $\underset{m}{\tilde{\omega}}$ & $\begin{array}{l}\text { To evaluate prospectively (5 years) } \\
\text { QoL in a cohort of patients with } \\
\text { FD, related to chronic organ } \\
\text { damage, pain rate and history of } \\
\text { complications related to the disease }\end{array}$ & Cohort Level IV \\
\hline & $\begin{array}{l}\text { Dampier et al } \mathrm{I}^{(17)} \text {. Health-related } \\
\text { quality of life in adults with sickle } \\
\text { cell disease (SCD): a report from } \\
\text { the comprehensive sickle cell } \\
\text { centers clinical trial consortium. }\end{array}$ & $\begin{array}{l}\text { Am J Hematol (A1), } \\
\text { 2011, USA }\end{array}$ & $\underset{m}{\stackrel{m}{\omega}}$ & $\begin{array}{c}\text { To examine the relationship } \\
\text { between the various } \\
\text { complications related to FD and } \\
\text { quality of life (QoL) }\end{array}$ & Cohort Level IV \\
\hline & $\begin{array}{l}\text { Anie et } \text { al }^{(18)} \text {. Patient self-assessment of } \\
\text { hospital pain, mood and health-related } \\
\text { quality of life in adults with SCD }\end{array}$ & $\begin{array}{c}\text { BMJ Open (B1), 2012, } \\
\text { USA }\end{array}$ & ڤ̊n & $\begin{array}{l}\text { Characterize the relationship } \\
\text { of pain with mood and QOL at } \\
\text { admission, before discharge and at } \\
\text { one post-discharge week }\end{array}$ & Transversal Level VI \\
\hline & $\begin{array}{l}\text { Ohara et al }{ }^{(19)} \text {. Musculoskeletal } \\
\text { pain, profile and quality of life of } \\
\text { individuals with SCD. }\end{array}$ & $\begin{array}{l}\text { Rev. bras. Fisioter (B1) } \\
2012 \text { Brazil }\end{array}$ & 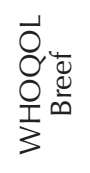 & $\begin{array}{l}\text { To verify the relationship between } \\
\text { musculoskeletal pain, considering } \\
\text { its body location, social, economic } \\
\text { and QoL characteristics in } \\
\text { individuals with DF }\end{array}$ & Transversal Level VI \\
\hline & $\begin{array}{l}\mathrm{Al} \text { Jaouni et al }{ }^{(20)} \text {. Treatment } \\
\text { adherence and quality of life } \\
\text { outcomes in patients with SDC }\end{array}$ & $\begin{array}{l}\text { Saudi Med J (B3), } \\
\text { 2013, Saudi Arabia }\end{array}$ & 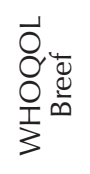 & $\begin{array}{l}\text { To evaluate the HRQOL of patients } \\
\text { with FD and to measure the impact } \\
\text { of adherence to treatment on } \\
\text { the complications of the disease, } \\
\text { severity, crises, and outcomes }\end{array}$ & Transversal Level VI \\
\hline & $\begin{array}{l}\text { Keller et } \mathrm{al}^{(7)} \text {. Patient reports of health } \\
\text { outcome for adults living with sickle } \\
\text { cell disease: development and testing } \\
\text { of the ASCQ-Me item banks. }\end{array}$ & $\begin{array}{c}\text { Health Qual Life } \\
\text { Outcomes (B1), 2014, } \\
\text { USA }\end{array}$ & 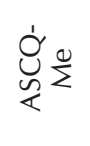 & $\begin{array}{l}\text { Develop Adult Sickle Cell Quality } \\
\text { of Life Measurement System } \\
\text { (ASCQ-Me) }\end{array}$ & Transversal Level VI \\
\hline & $\begin{array}{l}\text { Ahmed et al }{ }^{(21)} \text {. Health Qual Life } \\
\text { Outcomes Health- related quality of } \\
\text { life in patients with sickle cell disease } \\
\text { in Saudi Arabia. }\end{array}$ & $\begin{array}{l}\text { Health Qual Life } \\
\text { Outcomes (B1), } 2015 . \\
\text { Saudi Arabia }\end{array}$ & $\underset{m}{\stackrel{m}{\omega}}$ & $\begin{array}{l}\text { Describe the characteristics of } \\
\text { Saudi patients with FD and their } \\
\text { impact on QoL }\end{array}$ & Transversal Level VI \\
\hline 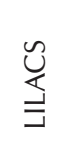 & $\begin{array}{l}\text { Pereira et al }{ }^{(22)} \text {. Sickle cell disease } \\
\text { and quality of life: a study on the } \\
\text { subjective perception of patients from } \\
\text { the Fundação Hemominas, Minas } \\
\text { Gerais, Brasil. }\end{array}$ & $\begin{array}{l}\text { Rev. bras. Hematol } \\
\text { Hemoter (B3), 2008, } \\
\text { Brazil }\end{array}$ & 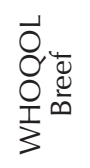 & $\begin{array}{l}\text { To investigate whether the concept } \\
\text { of QoL advocated by the World } \\
\text { Health Organization (WHO) could } \\
\text { be used for patients with DF }\end{array}$ & Qualitative VI \\
\hline
\end{tabular}




\begin{tabular}{|c|c|c|c|c|c|}
\hline Base & Author, title of article & $\begin{array}{l}\text { Periodic, classification, } \\
\text { year and country }\end{array}$ & Scale & Objectives & $\begin{array}{l}\text { Design and level } \\
\text { of evidence }\end{array}$ \\
\hline \multirow{6}{*}{ 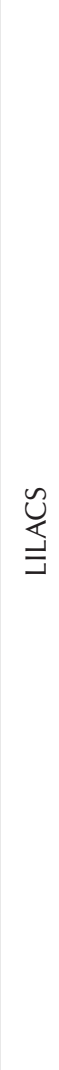 } & $\begin{array}{l}\text { Roberti et al }{ }^{(3)} \text {. Avaliação da } \\
\text { qualidade de vida em portadores } \\
\text { de doença falciforme do Hospital } \\
\text { das Clínicas de Goiás, Brasil. }\end{array}$ & $\begin{array}{l}\text { Rev. bras. Hematol } \\
\text { Hemoter (B3), 2010, } \\
\text { Brazil }\end{array}$ & 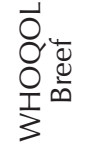 & $\begin{array}{l}\text { To evaluate the QOL of patients } \\
\text { with sickle cell disease treated } \\
\text { at Hospital das Clínicas, } \\
\text { Universidade de Goiás }\end{array}$ & Transversal Level VI \\
\hline & $\begin{array}{l}\text { Santos et al }{ }^{(23)} \text {. Sociodemographic } \\
\text { aspects and quality of life of patients } \\
\text { with SCA. }\end{array}$ & $\begin{array}{l}\text { Rev. bras. Hematol } \\
\text { Hemoter (B3), 2013, } \\
\text { Brazil }\end{array}$ & $\begin{array}{l}\stackrel{0}{n} \\
\dot{\omega}\end{array}$ & $\begin{array}{l}\text { To describe the sociodemographic } \\
\text { profile and the impact of the disease } \\
\text { on the QOL of patients with AF }\end{array}$ & Transversal Level VI \\
\hline & $\begin{array}{l}\text { Losilla et al }{ }^{(24)} \text {. Evaluating quality } \\
\text { of life in patients with sickle cell } \\
\text { disease: Differences between adults } \\
\text { and children. }\end{array}$ & $\begin{array}{c}\text { Medicina (RP) (B4), } \\
\text { 2013, Brazil }\end{array}$ & 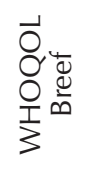 & $\begin{array}{c}\text { To describe and analyze the QoL } \\
\text { of patients with sickle cell anemia } \\
\text { at a hematology clinic of a school } \\
\text { hospital in the Southeast Region, } \\
\text { Brazil }\end{array}$ & Transversal Level VI \\
\hline & $\begin{array}{l}\text { Pereira et al }{ }^{(25)} \text {. Sickle Cell Disease: } \\
\text { quality of life in patients with } \\
\text { hemoglobin SS and SC disorders. }\end{array}$ & $\begin{array}{l}\text { Rev. bras. Hematol } \\
\text { Hemoter (B3), 2013, } \\
\text { Brazil }\end{array}$ & 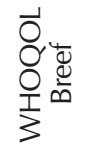 & $\begin{array}{c}\text { To evaluate the QoL of } \\
\text { patients with DF (HbSS and } \\
\text { HbSC) and their clinical and } \\
\text { sociodemographic characteristics }\end{array}$ & Transversal Level VI \\
\hline & $\begin{array}{l}\text { Mastandréa et al }{ }^{(26)} \text {. The } \\
\text { relationship between genotype, } \\
\text { psychiatric symptoms and quality } \\
\text { of life in adult patients with sickle } \\
\text { cell disease in São Paulo, Brazil: a } \\
\text { cross-sectional study. }\end{array}$ & $\begin{array}{c}\text { São Paulo Med J (B2), } \\
\text { 2015, Brazil }\end{array}$ & $\underset{m}{\infty}$ & $\begin{array}{l}\text { To describe the psychiatric } \\
\text { symptomatology present in the } \\
\text { Brazilian patient with sickle } \\
\text { cell disease and to evaluate the } \\
\text { relationship of these symptoms } \\
\text { with the genotype of the disease } \\
\text { and the subject's HRQL }\end{array}$ & Transversal Level VI \\
\hline & $\begin{array}{c}\text { Martínez-Triana et al }{ }^{(27)} \text {. Efecto de } \\
\text { la drepanocitosis sobre la calidad } \\
\text { de vida. }\end{array}$ & $\begin{array}{l}\text { Rev. cuba Hematol, } \\
\text { Inmunol Hemoter (SI), } \\
\text { 2015, Cuba }\end{array}$ & $\begin{array}{l}0 \\
\stackrel{m}{\omega}\end{array}$ & $\begin{array}{l}\text { To determine the HRQoL of adult } \\
\text { patients with DF who receive care } \\
\text { at the Institute of Hematology and } \\
\text { Immunology (IHI) }\end{array}$ & Control case IV \\
\hline 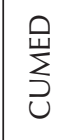 & $\begin{array}{l}\text { Martínez-Triana et al }{ }^{(2)} \text {. Cuestionario } \\
\text { para evaluar la calidad de vida } \\
\text { relacionada con la salud de adultos } \\
\text { con drepanocitosis. }\end{array}$ & $\begin{array}{l}\text { Rev. cuba Hematol, } \\
\text { Inmunol Hemoter (SI), } \\
\text { 2012, Cuba }\end{array}$ & $\begin{array}{l}\tilde{u} \\
\ddot{u}\end{array}$ & $\begin{array}{c}\text { Development and validation of a } \\
\text { specific questionnaire to evaluate } \\
\text { the QOL of patients with DF } \\
\text { (CEB-S) }\end{array}$ & Control case Level IV \\
\hline 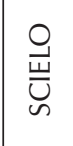 & $\begin{array}{l}\text { Vilela et al } \mathrm{l}^{(28)} \text {. Quality of life of } \\
\text { individuals with sickle cell disease } \\
\text { followed at referral centers in } \\
\text { Alagoas, Brasil. }\end{array}$ & $\begin{array}{l}\text { Rev. bras. Hematol } \\
\text { Hemoter (B3), 2012, } \\
\text { Brazil }\end{array}$ & $\begin{array}{l}0 \\
\tilde{m} \\
\omega\end{array}$ & $\begin{array}{l}\text { To evaluate the HRQoL of } \\
\text { individuals with FD followed at } \\
\text { reference centers in Alagoas, Brazil }\end{array}$ & Transversal Level VI \\
\hline
\end{tabular}

Note: MEDLINE, LILACS, CUMED, SCIELO, SF36 (Medical Outcome Study 36 item Short Form), SIMS (Sickle Cell Impact Measuring Scale), WHOQOL Breef (World Health Organization Quality of Life Assessment Instrument Bref), EQ-5D (EuroQol), ASCQ-Me (Adult Sickle Cell Quality of Life Measurement System), CEB-S (Cuestionario específico sobre calidad de vida en drepanocitosis).

\section{Socio-demographic and genotype aspects of study par- ticipants}

Among the 22 articles selected, the majority of the participants were: women in $21(95.5 \%)^{(1-5,7,13-18,20-28)}$, with $\mathrm{HbSS} / \mathrm{S} \beta^{\mathbf{0}}$ Tal genotypes in $19(86.4 \%)^{(1-2,4-5,7,13-17,19-20,22-28)}$; unmarried children in $13(59.1 \%)^{(1,3-5,13,15,20-27)}$ and low schooling $12(54.5 \%)$ $(3,5,13,15-16,20-25,28)$.

\section{Scales used to assess health-related quality of life}

This review demonstrated that six HRQoL assessment scales were used, three generic and three specific. The generic ones were: Medical Outcome Study 36 item Short Form - SF36 ( $\mathrm{n}=11)^{(1,4,13-14,16-17,21,23,26-28)}$; World Health Organization Quality of Life Assessment Instrument Bref WHOQOL-Bref $(\mathrm{n}=7)^{(3,15,19-20,22,24-25)}$ and EuroQol EQ-5D $(\mathrm{n}=1)^{(18)}$.
Three articles described the development of specific scales to evaluate the HRQoL of adults with FD: specific questionnaire on quality of life in sickle cell disease - CEB-S(2), Sickle Cell Impact Measurement Scale (SIMS) and Adult Sickle Cell Quality of Life Measurement System - ASCQ-Me ${ }^{(7)}$.

\section{Quality of life of patients with sickle cell disease}

Patients with FD had QOL $(n=6)^{(3,12,14,23,26,28)}$, HRQoL worse than the general population $(n=3)^{(13,14,27)}$, work $(n=3)^{(22-23,25)}$ and low-paid jobs $(n=1)^{(23)}$.

One study showed that symptoms of depression were present in $30 \%$ of participants, anxiety symptoms in $12.7 \%$ and alcohol abuse in $9.1 \%{ }^{(26)}$. It was also possible to verify that pain ${ }^{(13,15-19,25,28)}$ and psychological distress ${ }^{(18)}$ contributed to reduce the HRQoL scores, and their score was significantly reduced when pain levels increased $^{(13)}$. 
Chart 2 - Distribution of adult patients with sickle cell disease according to health-related quality of life scores

\begin{tabular}{|c|c|}
\hline Patients who presented lower health-related quality of life scores & Patients who presented higher health-related quality of life scores \\
\hline $\begin{array}{l}\text { - symptomatic }(n=1)^{(2)} \\
\text { - who had frequent painful crises }(n=9)^{(2,13-15-19,25,28)} \\
\text { - with severe form of the disease }(n=8)^{(1,2,13,16-18,26,28)} \\
\text { - with frequent hospitalizations }(n=1)^{(25)} \\
\text { - who needed blood transfusions }(n=2)^{(21,25)} \\
\text { - with comorbidities or complications imposed by the disease }(n=3)^{(17,20,25)} \\
\text { - with lower hemoglobin levels }(n=1)^{(2)} \\
\text { - who did not adhere to or with late onset of treatment }(n=1)^{(20)} \\
\text { - who declared themselves victims of prejudice due to the disease }(n=1)^{(3)} \\
\text { - with mood disorder }(n=1)^{(28)}\end{array}$ & $\begin{array}{l}\text { - with double heterozygosity }(\mathrm{HbSC})(\mathrm{n}=3)^{(1,17,26)} \\
\text { - with less severe forms of sickle cell disease }(\mathrm{n}=3)^{(1,7,17)} \\
\text { - who lived in rural areas }(\mathrm{n}=1)^{(1)} \\
\text { - married }(\mathrm{n}=2)^{(5,28)} \\
\text { - women }(\mathrm{n}=1)^{(5)} \\
\text { - employees }(\mathrm{n}=3)^{(1,18,21)} \\
\text { - with income above } \$ 30,000 \text { per year }(\mathrm{n}=1)^{(5)} \\
\text { - with } 12 \text { years of schooling or more }(\mathrm{n}=3)^{(5,18,21)} \\
\text { - under treatment with hydroxyurea }(\mathrm{n}=1)^{(14)} \\
\text { - who received effective treatments for pain and depression }(\mathrm{n}=1)^{(17)} \\
\text { - with early medical intervention and adherence to treatment }(\mathrm{n}=1)^{(20)} \\
\text { - with regular physical activity }(\mathrm{n}=1)^{(21)}\end{array}$ \\
\hline
\end{tabular}

\section{DISCUSSION}

The present study proved that the integrative literature review is capable of systematically, orderly and synthesized the results of researches, which contributes to increase knowledge about HRQoL in people with FD.

Due to the technological advances in the area of health, there was an increase in the survival of the people and, consequently, also the prevalence of chronic-degenerative diseases and their sequels increased.

The increase in life expectancy has resulted in an increase in the number of people with chronic diseases, that is, those that are not curable ${ }^{(29)}$. In these cases, the goal of care no longer resides simply in healing, and now includes promoting improvements in the lives of these patients. In recent decades, the international scientific community has been increasingly interested in studying the concept of QOL, a fact observed in this review study, in which it was possible to verify that the concern with the QoL of people with FD is increasing, since the majority $(63.6 \%)$ of the articles selected for this study was published between the years 2010 and 2015 .

Studies have shown that patients diagnosed with chronic diseases have a higher risk of developing stress, anxiety and depression, as well as the consequent impairment of their QoL index ${ }^{(30)}$, whose evaluation provides pertinent information that supports the planning of effective actions for such patients ${ }^{(31)}$.

It was verified that evaluation of the patient's QoL is recognized as an important area of scientific knowledge, since the instruments used to evaluate the patient's perception regarding their HRQOL are multidimensional, measuring changes in the physical, functional, psychological and social aspects, as well as self-assessment of their state of health.

Of the four keyword associations used in this review, three (A, C, and D) provided results and the majority (86.4\%) of the articles had been published in English. Using the associations, 253 publications were found in Portuguese (31.5\%), $521(65.0 \%)$ and Spanish $28(2.5 \%)$. These results prove that choosing to use keyword associations in all three languages was the best option.

The observation of the level of evidence of each study is important to establish the reliability of the results that will be used and, in this way, to strengthen the conclusions that will come from the research in development. The studies can be classified into seven levels of evidence, namely: Level I - systematic review or meta-analysis, coming from all relevant randomized controlled clinical trials; Level II - randomized clinical trial; Level III - non-randomized clinical trial; Level IV - cohort or case-control studies; Level $\mathrm{V}$ - systematic review of descriptive and qualitative studies; Level VI - descriptive or qualitative study and Level VII - studies whose evidence comes from the opinion of authorities and / or report of expert committees ${ }^{(12)}$.

\section{Socio-demographic and genotype aspects of study participants}

The majority of respondents who participated in the surveys had low levels of schooling. Studies in the US ${ }^{(5)}$ and Cuba $^{(27)}$ have shown that patients with schooling aged 12 years or more had higher HRQL scores.

Several authors have shown that low schooling can negatively influence the evolution of chronic disease, due to the compromised ability to read and understand orientations during health education actions ${ }^{(31-32)}$, resulting in failure to adopt healthy behaviors and adherence to treatment and, consequently, to lower QOL scores ${ }^{(33-36)}$.

As for the marital situation, it was found that most of the participants denied being married or living marital with anyone. Several studies have shown that married or companion patients had higher HRQL scores ${ }^{(5,22,28)}$.

Women constituted the majority of the sample in $95.5 \%$ of the articles selected for this review. The FD is not a disease influenced by gender, however, women make more use of health services than men and are more likely to negatively assess their health status ${ }^{(23)}$.

It is believed that the demand for health services does not occur solely through necessity, but through different determinations that explain the variations between social groups, among them, the different social roles that men and women play in society and the way in which both express their disease ${ }^{(30)}$. There were predominant forms of severe DF ( $\mathrm{HbSS}$ or $\left.\mathrm{S} \beta^{\circ} \mathrm{Tal}\right)$ in 20 articles and, in two, the genotype was not reported. HbSS is the most prevalent genotype in Bra$\mathrm{zil}^{(3,19,22,25,28)}$ and in the world ${ }^{(1-2,5,7,13,15,17,20,27)}$ and is often associated with a lower life expectancy ${ }^{(37-38)}$. 


\section{Quality of life of patients with sickle cell disease}

In six studies, the patients interviewed reported several limitations with a decrease in $\operatorname{QoL}^{(16,20,23,26,28)}$. FD is a chronic and therefore limiting disease, especially when it occurs in the most severe forms. Chronic diseases interfere with patients' ability to perform their daily activities, which may lead to temporary or permanent disability, as well as irreversible damage to the functioning of various organs, causing work impediment and leading to a decrease in $\mathrm{QoL}^{(23)}$. HbSS and $S \beta$-tal, more severe forms of FD, are associated with lower scores on QOL ${ }^{(2,13,16,26)}$.

The main manifestation of DF is the painful crisis $^{(16)}$, caused by vaso-occlusion, due to the falcization of red blood cells. The pain is intense, abrupt onset and is the major cause of hospitalization. Many patients with frequent episodes of painful crises presented lower HRQoL scores and significant decrease of the score when their pain levels increased ${ }^{(13)}$. Pain is considered the main cause of physical and emotional destabilization of patients with $\mathrm{DF}^{(17)}$.

Patients with complications caused by the disease (pain crises and those requiring opioids, hospitalizations, blood transfusions, among others) presented HRQL worse than the general population ${ }^{(2,13,15-21,25,28)}$; neurobehavioral comorbidities (anxiety, attention or behavior problems, depression, developmental delay or mental retardation, sleep disturbances, learning difficulties, seizures or speech problems) ${ }^{(20)}$; (history of stroke, acute chest syndrome, recurrent priapism, more than three hospitalizations due to vaso-occlusive crisis in the last three years, bone complications, clinical conditions requiring transfusions and frequent hospitalizations) ${ }^{(17,19-20,25)}$.

A study developed in the USA by Dampier et al., Showed that the number of complications increased substantially with age, but only a few (vaso-occlusive pain or opioid use) significantly influenced the reduction of HRQoL in adults with FD. The researchers suggested that more effective treatments for persistent pain and depression would contribute to the better QoL of these patients ${ }^{(17)}$.

The way each person perceives pain is unique, subjective, and unique. This perception is influenced by sensory, cognitive, affective and socio-behavioral factors ${ }^{(39)}$.

In the research conducted by van Tuijn et al., in the Netherlands, it was possible to observe that the QOL scores in patients with FD appear to be determined mainly by the pain and social circumstances (occupation and educational level) and that, despite the contribution of cumulative organ damage, such as mild pulmonary hypertension on prognosis and life expectancy, do not seem to be determinants of QOL in $\mathrm{FD}^{(16)}$.

Patients with lower $\mathrm{Hb}^{(2)}$, mood disorder, low schooling, lower income, single and non-adherent to treatment or who started late had also had lower HRQoL scores. On the other hand, patients with dual heterozygosity with less severe forms of FD who lived in a rural area, married, had a job, had high schooling(5) and practiced regular physical exercise, scored HRQOL better ${ }^{(21)}$.

Research developed by Ahmed et al. ${ }^{(21)}$ demonstrated that regular exercise tends to decrease pain and improve social function and vitality. This research suggested the importance of regular exercises in controlling the burden of disease through the development of physical training programs for people living with FD. However, the authors also reported that interventional studies are needed to evaluate the role of regular physical activity in the HRQoL of patients with FD.

It is observed that the interventions whose objectives are to adequately control pain in the crisis, improve vitality and mental health ${ }^{(17,28)}$, prevent pain crises (such as the use of hydroxyurea) ${ }^{(14)}$, early medical intervention and in encouraging treatment adherence ${ }^{(20)}$ may contribute to the maintenance of high levels of QoL in patients with FD.

\section{Scales used to assess health-related quality of life}

The majority $(86.36 \%)$ of the articles selected used generic HRQoL scales. Generic instruments have the advantage of evaluating several areas or domains in diverse populations, which allows comparisons between patients with different diseases, but may be unable to demonstrate changes in some specific aspects ${ }^{(9,17)}$.

In this review, it was observed that the most used $\mathrm{HRQOL}$ assessment scale was SF36 $(\mathrm{n}=11)$. It is a generic, multidimensional scale, consisting of 36 items, divided into eight domains: Functional Capacity, Physical Aspects, Emotional Aspects, Pain, General Health Status, Vitality, Social Aspects and Mental Health. It is one of the instruments most frequently used for HRQL measurements and has been adopted in several studies on chronic diseases for evaluating both the positive and negative aspects of the disease $\mathrm{e}^{(1,4,13-14,16-17,21,23,26-28)}$.

The WHOQOLBref scale, used in seven studies ${ }^{(3,15,19-20,22,24-25)}$ selected for this review, is composed of 26 questions, the first of which concerns the individual perception of quality of life and the second, to the individual's perception of health. The remaining 24 questions comprise four domains: Physical, Psychological, Social and Environmental. The EQ-5D, a scale used by one of the sample studies, was developed by the EuroQoL group in the late 1980s. It allows the generation of an index representing the value of an individual's health status. Its five dimensions are: mobility, personal care, usual activities, pain / malaise and anxiety / depression ${ }^{(18,40)}$.

Three studies participating in the study discussed the development of specific scales to evaluate the HRQoL of adults with FD: CEB-S(2), SIMS ${ }^{(5)}$ and ASCQ-Me ${ }^{(7)}$. The specific instruments, usually also multidimensional, although they do not allow comparisons between patients with different pathologies, are shown to be clinically more sensitive, since they are developed to evaluate in more detail the HRQoL of patients considering specific aspects of a certain disease ${ }^{(9,29)}$.

The CEB-S, created in Cuba, is composed of 30 issues, divided into four domains: physical area, emotional area, social area and pain ${ }^{(2)}$.

SIMS was developed by researchers at the University of Tennessee, USA, and is composed of 142 multidimensional items. Each of them is inserted in one of four domains: pain, physical function, emotional well-being and social functioning(5).

Another specific scale found in this review was the ASCQMe, also developed in the USA. It is a multidimensional questionnaire, composed of 92 items, divided into six sets of questions (domains): cognitive impact, emotional impact, sleep impact, social functioning, pain and stiffness ${ }^{(7)}$. 


\section{Limitations of the study}

Although necessary, inclusion criteria may impose limitations on the study. For this review, four databases (MEDLINE, CUMED, LILACS and SciELO) were selected, which was a limiting factor, since the journals not indexed there were not selected for the sample. In addition, three studies were excluded because they were published in languages other than those set out in the inclusion criteria (Portuguese, English and Spanish).

Although the English language is used in most scientific studies, it is believed that research that includes other databases and publications in other languages may contribute to broaden the findings of this review.

\section{Contributions to the nursing area}

It is hoped that this review may stimulate reflection and debate among nurses and other health professionals about the importance of assessing the quality of life of adult patients with sickle cell disease.

The knowledge of the HRQoL of these people makes it possible to subsidize the work of the health team with data relevant to the elaboration of interventions, programs and health policies that aim to improve their QoL.

\section{CONCLUSION}

This review showed that the concern with QOL of adult patients with DF is not recent, but has been growing. It has also demonstrated that the disease has high morbidity and mortality, with varied and intense clinical manifestations, which include pain, infections and multiple organ failure, which has an impact on patients' QoL, which have worse HRQoL scores than the general population
There are several factors that may negatively affect the HRQoL of adults with FD such as: intensity and frequency of painful crises, need for hospitalization and blood transfusion, non-adherence to treatment or late onset, and social circumstances (marital status, unemployment, low schooling and low economic power).

Studies show that patients with FD who adhere to treatment and those in whom the intervention is early have better HRQL results. In addition, it is known that the lower HRQL scores were related to impaired functional capacity, physical limitations and limitations due to emotional aspects. Thus, it is believed that early intervention, with more effective treatments for persistent pain and depression, can bring great benefit in HRQoL.

Three articles portrayed the elaboration of specific scales to evaluate QOL of adults with FD; however, in this review, it was verified that none of them had been used in Brazilian patients, which evidenced the need to perform the transcultural translation and adaptation of these scales into Portuguese. This discovery motivated the lead author to initiate the process of translation and cultural adaptation of the SIMS scale, with the consent of its developer group.

In light of the above, it was verified that HRQoL measures should be applied in all centers treating patients with DF in order to subsidize nurses in the planning of their care, education and social interventions and in proposing strategies aimed at improving the QV of this clientele.

\section{FUNDING}

The financial support granted by the Foundation for Support to the Development of Education, Science and Technology of the State of Mato Grosso do Sul - FUNDECT and the Coordination for the Improvement of Higher Education Personnel - CAPES, should be gratefully acknowledged.

\section{REFERENCES}

1. Asnani MR, Reid ME, Ali SB, Lipps G, Williams-Green P. Quality of life in patients with sickle cell disease in Jamaica: ruralurban differences. Rural Remote Health [Internet]. 2008[cited 2015 Jul 21];8(2):1-9. Available from: http://www.rrh.org.au/ publishedarticles/article_print_890.pdf

2. Martínez-Triana R, Martínez-Rodríguez M, Guerra-Romero C, Guerra-González EM, Machado-Almeida T, Machín-García S, et al. Cuestionario para evaluar la calidad de vida relacionada con la salud de adultos con drepanocitosis. Rev Cuba Hematol Inmunol Hemoter [Internet]. 2012[cited 2016 May 28];28:385-97. Available from: http://scielo.sld.cu/pdf/hih/v28n4/hih07412.pdf

3. Roberti MDRF, Moreira CLNSO, Tavares RS, Borges Filho HM, Silva AG, Maia CHG, et al. Evaluation of quality of life of patients with sickle cell disease in a General Hospital of Goiás, Brazil, Brasil. Rev Bras Hematol Hemoter[Internet]. 2010 [cited 2016 Apr 28];32:449-54. Available from: http://www.scielo.br/pdf/rbhh/v32n6/08.pdf

4. Asnani MR, Lipps GE, Reid ME. Component structure of the SF-36 in Jamaicans with sickle cell disease. West Indian Med J[Internet]. 2007[cited 2016 Jan 02];56(6):491-7. Available from: http://caribbean.scielo.org/pdf/wimj/v56n6/a04v56n6.pdf

5. Adams-Graves P, Lamar K, Johnson C, Corley P. Development and validation of SIMS: An instrument for measuring quality of life of adults with sickle cell disease. Am J Hematol[Internet]. 2008[cited 2016 May 30];83(7):558-62. Available from: http:// onlinelibrary.wiley.com/doi/10.1002/ajh.21146/pdf

6. The WHOQOL Group. The World Health Organization Quality Of Life Assessment (WHOQOL): position paper from the World Health Organization. Soc Sci Med[Internet]. 1995[cited 2016 Feb 02];41(10):1403-9. Available from: http://www.ncbi.nlm.nih. gov/pubmed/8560308

7. Keller SD, Yang M, Treadwell MJ, Werner EM, Hassell KL. Patient reports of health outcome for adults living with sickle cell disease: development and testing of the ASCQ-Me item banks. Health Qual Life Outcomes[Internet]. 2014[cited 2016 Apr 30];12(1):1-11. 
Available from: http://www.hqlo.com/content/12/1/125

8. Ciconelli RM, Ferraz MB, Santos W, Meinão I, Quaresma MR. Brazilian-Portuguese version of the SF-36. A reliable and valid quality of life outcome measure. Rev Bras Reumatol. 1999;39(3):143-50.

9. Campolina AG, Ciconelli RM. Quality of life and utility measures: clinical parameters for decision-making in health. Rev Panam Salud Pública [Internet]. 2006[cited 2016 Sep 21];19:128-36. Available from: http://www.scielosp.org/pdf/rpsp/v19n2/30312.pdf

10. Polit DF, Beck CT. Using research in evidence-based nursing practice. In: Polit DF, Beck CT, editors. Essentials of nursing research: methods, appraisal and utilization. Philadelphia (USA): Lippincott Williams \& Wilkins; 2006. p.457-94.

11. Ganong LH. Integrative reviews of nursing research. Res Nurs Health[Internet]. 1987[cited 2016 May 10];10:1-11. Available from: http://www.ncbi.nlm.nih.gov/pubmed/3644366

12. Melnyk BM, Fineout-Overholt E. Making the case for evidence-based practice. In: Melnyk BM, FineoutOverholt E, (Eds.). Evidencebased practice in nursing and healthcare: a guide to best practice. Philadelphia: Lippincott Williams and Wilkins; 2005. p. 3-24.

13. McClish DK, Penberthy LT, Bovbjerg VE, Roberts JD; Aisiku IP, Levenson JL, et al. Health related quality of life in sickle cell patients: The PiSCES project. Health Qual Life Outcomes[Internet]. 2005[cited 2016 Jun 25];3(50):1-7. Available from: http:// www.ncbi.nlm.nih.gov/pmc/articles/PMC1253526/

14. Ballas SK, Barton FB, Waclawiw MA, Swerdlow P, Eckman JR, Pegelow CH, et al. Hydroxyurea and sickle cell anemia: effect on quality of life. Health Qual Life Outcomes[Internet]. 2006[cited 2016 May 27];4(59):1-8. Available from: http://www.hqlo.com/ content/pdf/1477-7525-4-59.pdf

15. Asnani, M, Lipps G, Reid M. Utility of WHOQOL-BREF in measuring quality of life in sickle cell disease. Health Qual Life Outcomes[Internet]. 2009[cited 2016 Jul 26];7(75):1-6. Available from: http://www.smj.org.sa/index.php/smj/article/viewFile/771/407

16. van Tuijn CF, van Beers EJ, Schnog JJ, Biemond BJ. Pain rate and social circumstances rather than cumulative organ damage determine the quality of life in adults with sickle cell disease. Am J Hematol [Internet]. 2010[cited 2016 Oct 13];85(7):532-5. Available from: http://onlinelibrary.wiley.com/doi/10.1002/ajh.21731/epdf

17. Dampier C, LeBeau P, Rhee S, Lieff S, Kesler K, Ballas S, et al. Health-related quality of life in adults with sickle cell disease (SCD): a report from the comprehensive sickle cell centers clinical trial consortium. Am J Hematol[Internet]. 2011 [cited 2016 Aug 18];86(2):203-5. Available from: http://onlinelibrary.wiley.com/doi/10.1002/ajh.21905/pdf

18. Anie KA, Grocott H, White L, Dzingina M, Rogers G, Cho G. Patient self-assessment of hospital pain, mood and health-related quality of life in adults with sickle cell disease. BMJ Open[Internet]. 2012 [cited 2016 Oct 12];2(4):1-6. Available from: http:// bmjopen.bmj.com/content/2/4/e001274.full.pdf +html

19. Ohara DG, Ruas G, Castro SS, Martins PR, Walsh IA. Musculoskeletal pain, profile and quality of life of individuals with sickle cell disease. Rev Bras Fisioter [Internet]. 2012[cited 2016 Oct 13];16(5):431-8. Available from: http://www.scielo.br/pdf/rbfis/v16n5/ pt_aop040_12.pdf

20. Al Jaouni SK, AI Muhayawi MS, Halawa TF, AI Mehayawi MS. Treatment adherence and quality of life outcomes in patients with sickle cell disease. Saudi Med J[Internet]. 2013[cited 2016 Jun 08];34(3):261-5. Available from: http://www.smj.org.sa/index.php/ smj/article/viewFile/771/407

21. Ahmed AE, Alaskar AS, Al-Suliman AM, Jazieh AR, McClish DK, Al Salamah M, et al. Health-related quality of life in patients with sickle cell disease in Saudi Arabia. Health Qual Life Outcomes[Internet]. 2015[cited 2016 Jul 18];13:183. Available from: http:// www.ncbi.nIm.nih.gov/pmc/articles/PMC4647668/

22. Pereira SAS, Cardoso CS, Brener S, Proietti ABFC. Sickle cell disease and quality of life: a study on the subjective perception of patients from the Fundação Hemominas, Minas Gerais, Brazil. Rev Bras Hematol Hemoter[Internet]. 2008[cited 2016 Oct 25];30(5):411-6. Available from: http://www.scielo.br/pdf/rbhh/v30n5/v30n5a15.pdf

23. Santos JP, Gomes Neto M. Sociodemographic aspects and quality of life of patients with sickle cell anemia. Rev Bras Hematol Hemoter[Internet]. 2013[cited 2016 Oct 25];35(4):242-5. Available from: http://www.scielo.br/pdf/rbhh/v35n4/1516-8484rbhh-35-04-0242.pdf

24. Losilla M, Lima RS, Mello LM, Silva, AS, Nunes AA, Miranzi SC. Evaluating quality of life in patients with sickle cell disease: differences between adults and children. Medicina (RP)[Internet]. 2013[cited 2016 Jun 15];46(2):164-70. Available from: http:// revista.fmrp.usp.br/2013/vol46n2/ao_Avalia \%E7\%E3o\%20da $\%$ 20qualidade $\% 20 \mathrm{de} \% 20 \mathrm{vida} \% 20 \mathrm{em} \% 20$ pacientes $\% 20$ com $\% 20$ anemia\%20falciforme.pdf

25. Pereira SAS, Brener S, Cardoso CS, Proietti ABFC. Sickle Cell Disease: quality of life in patients with hemoglobin SS and SC disorders. Rev Bras Hematol Hemoter[Internet]. 2013[cited 2016 Oct 25];35(5):325-31. Available from: http://www.ncbi.nlm.nih. gov/pmc/articles/PMC3832312/pdf/rbhh-35-05-0325.pdf

26. Mastandréa EB, Lucchesi F, Kitayama MMG, Figueiredo MS, Citero VA. The relationship between genotype, psychiatric symptoms and quality of life in adult patients with sickle cell disease in São Paulo, Brazil: a cross-sectional study. Sao Paulo Med J[Internet]. 2015[cited 2016 Oct 22];133(5):421-7. Available from: http://www.scielo.br/pdf/spmj/v133n5/1516-3180-spmj-2015-00171105.pdf

27. Martínez-Triana R, García-Hernández A, Guerra-González EM, Machado-Almeida T, Reytor-Alfonso K. Efecto de la drepanocitosis sobre la calidad de vida. Rev Cuba Hematol Inmunol Hemoter[Internet]. 2015[cited 2016 Oct 12];31(3):267-87. Available from: http://scielo.sld.cu/pdf/hih/v31n3/hih06315.pdf 
28. Vilela RQB, Cavalcante FC, Cavalcante BF, Araujo DL, Lobo MM, Nunes FAT. Quality of life of individuals with sickle cell disease followed at referral centers in Alagoas, Brazil. Rev Bras Hematol Hemoter[Internet]. 2012[cited 2016 Oct 12];34(6):442-6. Available from: http://www.scielo.br/pdf/rbhh/v34n6/v34n6a14.pdf

29. Aguiar CCT, Vieira APGF, Carvalho AF, Montenegro-Junior RM. Assessment instruments for a Health-Related Quality of Life in diabetes mellitus. Arq Bras Endocrinol Metab[Internet]. 2008[cited 2016 Jun 30];52(6):931-9. Available from: http://www.scielo. br/pdf/abem/v52n6/04.pdf

30. Travassos C, Viacava F, Pinheiro R, Brito A. Utilization of health care services in Brazil: gender, family characteristics, and social status. Rev Panam Salud Publica[Internet]. 2002[cited 2016 Sep 29];11(5/6):365-73. Available from: http://www.scielosp.org/pdf/ $\mathrm{rpsp} / \mathrm{v} 11 \mathrm{n} 5-6 / 10721 . \mathrm{pdf}$

31. Perkins AJ, Stump TE, Monahan PO, McHorney CA. Assessment of differential item functioning for demographic comparisons in the MOS SF-36 health survey. Qual Life Res [Internet]. 2006[cited 2016 Aug 23];15(3):331-48. Available from: http://www.ncbi. nlm.nih.gov/pubmed/16547771

32. Lima MG, Barros MBA, César CLG, Goldbaum M, Carandina L, Ciconelli RM. Health related quality of life among the elderly: a population-based study using SF-36 survey. Cad Saúde Pública[Internet]. 2009[cited 2016 May 26];25(10):2159-67. Available from: http://www.scielo.br/pdf/csp/v25n10/07.pdf

33. Andrade JMO, Rios LR, Teixeira LS, Vieira FS, Mendes DC, Vieira MA et al. Influence of socioeconomic factors on the quality of life of elderly hypertensive individuals. Ciênc Saúde Colet[Internet]. 2014[cited 2016 Oct 21];19(8):3497-504. Available from: http://www.scielo.br/pdf/csc/v19n8/1413-8123-csc-19-08-03497.pdf

34. Roca-Cusachs A, Badia X, Dalfo A, Gascon G, Abellan J, Lahoz R, et al. Relationship between clinical and therapeutic variables and health-related quality of life in patients with hypertension: minichal Study. Med Clin (Barc)[Internet]. 2003 [cited 2016 Oct 21];121(1):12-17. Available from: http://www.ncbi.nlm.nih.gov/pubmed/12812703

35. Li W, Liu L, Puente JG, Li Y, Jiang X, Jin S et al. Hypertension and health-related quality of life: an epidemiological study in patients attending hospital clinics in China. J Hypertens[Internet]. 2005[cited 2016 Oct 21];23(9):1667-76. Available from: http://www. ncbi.nlm.nih.gov/pubmed/16093911

36. Sprangers MA, Regt EB, Andries F, Van Agt HM, Bijl RV, Boer JB et al. Which chronic conditions are associated with better or poorer quality of life? J Clin Epidemiol[Internet]. 2000[cited 2016 Oct 21];53(9):895-907. Available from: http://www.ncbi.nlm. nih.gov/pubmed/11004416

37. Platt OS, Brambilla DJ, Rosse WF, Milner PF, Castro O, Steinberg MH et al. Mortality in sickle cell disease: life expectancy and risk factors for early death. N Engl J Med[Internet]. 1994[cited 2016 Jan 15];330(23):1639-44. Available from: http://www.ncbi. nlm.nih.gov/pubmed/7993409

38. Wierenga KJJ, Hambleton IR, Lewis NA. Survival estimates for patients with homozygous sickle-cell disease in Jamaica: a clinicbased population study. Lancet[Internet]. 2001[cited 2016 Jul 26];357(92):680-3. Available from: http://www.ncbi.nlm.nih.gov/ pubmed/11247552

39. Sousa FF, Silva JD. A métrica da dor (dormetria): problemas teóricos e metodológicos. Rev Dor, Pesq Clín Terap. 2005; 6(1):469-513.

40. Ferreira PL, Ferreira LN, Pereira LN. Contribution for the Validation of the Portuguese Version of EQ-5D. Acta Med Port[Internet]. 2013[cited 2016 Jul 26];26(6):664-75. Available from: http://www.actamedicaportuguesa.com/revista/index.php/amp/article/ viewFile/1317/3908 